\title{
EVOLUTIONARY ASPECTS OF CRASSULACEAN ACID METABOLISM
}

\author{
Fernanda Reinert ${ }^{1 *} \&$ Robert E. Blankenship ${ }^{2}$ \\ ${ }^{1}$ Universidade Federal do Rio de Janeiro (UFRJ), Instituto de Biologia, Departamento de Botânica, Ilha do Fundão, Rio de Janeiro, Brasil. \\ CEP: 21951-290. \\ ${ }^{2}$ Washington University in St. Louis, Departments of Biology and Chemistry, St. Louis, MO 63130, USA. \\ E-mails: freinert@biologia.ufrj.br, blankenship@wustl.edu
}

\begin{abstract}
Crassulacean acid metabolism (CAM) is a carbon concentrating metabolism present in more than 30 botanical families. This metabolism is often associated with water stressed environments although it can be found among aquatic plants. CAM's main feature is nighttime stomatal opening and acid accumulation due to $\mathrm{CO}_{2}$ fixation into a four carbon organic acid, often malate. CAM is present among pteridophytes, gymnosperms and angiosperms, in monocotyledonous and dicotyledonous species. Within some families, such as Crassulaceae, Orchidaceae and Bromeliaceae, CAM is widely represented. The genus Clusia has both facultative and constitutive CAM species. Regulation of the diel cycle of CAM hinges on the activation status of phosphoenolpyruvate carboxylase, responsible for fixation of $\mathrm{CO}_{2}$ at night. This enzyme is in turn regulated by phosphoenolpyruvate carboxykinase, a dedicated phosphorylating enzyme which is under circadian control. As CAM is widely distributed among botanical families, its origin is believed to be polyphyletic; however, the evolutionary mechanisms which allowed reappearance of this complex metabolism are not yet understood. Perhaps the answer relies on viewing $\mathrm{CAM}$ as a network that evolved by gene duplication from the pre-existing non photosynthetic $\mathrm{C}_{4}$ cycle. Keywords: Carbon concentrating mechanisms; photosynthesis; carbon isotope; PEPC; CAM in angiosperms.
\end{abstract}

\section{RESUMO}

ASPECTOS EVOLUTIVOS DO METABOLISMO ÁCIDO DAS CRASSULACEAS. O metabolismo ácido das crassuláceas (CAM) é um metabolismo fotossintético de concentração de $\mathrm{CO}_{2}$ presente em mais de 30 famílias botânicas. Está frequentemente associado à economia de água, embora esteja presente também em espécies aquáticas. CAM é caracterizado pela abertura dos estômatos à noite com acúmulo de ácidos em função da fixação de carbono em compostos de quatro carbonos, em geral, o malato. CAM está presente em pteridófitas, gimnospermas e angiospermas, tanto mono quanto dicotiledôneas. Em algumas famílias, como Crassulaceae, Orquidaceae e Bromeliaceae, o metabolismo ácido das crassuláceas está fortemente representado. No gênero Clusia, CAM pode estar presente nas espécies de forma facultativa ou constitutiva. A regulação do ciclo diurno do metabolismo ácido das crassuláceas é fortemente determinada pela regulação da enzima fosfoenolpiruvato carboxilase, responsável pela fixação do $\mathrm{CO}_{2}$ durante a noite. Por sua vez, sua regulação é feita através da fosforilação pela enzima fosfoenolpiruvato carboxiquinase que apresenta ritmo circadiano. Como a distribuição de CAM é descontínua acredita-se que sua origem seja polifilética, contudo, não estão claros os mecanismos evolutivos que tornaram o reaparecimento desse complexo metabolismo possível. Talvez CAM possa ser visto como um complexo que evoluiu por duplicação de genes do pré-existente não fotossintético ciclo $\mathrm{C}_{4}$. Palavras-chave: Mecanismos de concentração de carbono; fotossíntese; isótopo de carbono; PEPC; CAM em angiospermas.

\section{RESUMEN}

ASPECTOS EVOLUTIVOS DEL METABOLISMO ACIDO DAS CRASSULACEAS. El metabolismo ácido de las Crassuláceas (CAM) es un metabolismo fotosintético de concentración de $\mathrm{CO}_{2}$ presente en más de 30 familias botánicas. Está frecuentemente asociado a la economía de agua, a pesar de estar presente también en especies acuáticas. El CAM se caracteriza por la abertura de los estomas en la noche, y con la acumulación de ácidos en función de la fijación de carbono en compuestos de cuatro carbonos, en general, o malato. El 
CAM está presente en Pteridófitas, Gimnospermas e angiospermas, tanto mono como dicotiledóneas. En algunas familias, como Crassulaceae, Orquidaceae y Bromeliaceae, el metabolismo ácido de las Crassuláceas está fuertemente representado. En el género Clusia, el CAM puede estar presente en las especies de forma facultativa o constitutiva. La regulación del ciclo diurno del metabolismo ácido de las Crassuláceas es fuertemente determinada pela regulación de la enzima fosfoenolpiruvato carboxilasa, responsable por la fijación de $\mathrm{CO}_{2}$ durante la noche. A su vez, la regulación es realizada a través de la fosforilación que ejecuta la enzima fosfoenolpiruvato carboxiquinasa que presenta ritmo circadiano. Como la distribución de CAM es discontinua se cree que su origen sea polifilético, sin embargo, no están claros los mecanismos evolutivos que tornaron el reapareciendo de este complejo metabolismo posible. Tal vez CAM posa ser visto como un complejo que evoluciono por duplicación de genes del pré-existente no fotosintético ciclo $\mathrm{C}_{4}$.

Palabras clave: Mecanismos de concentración de carbono; fotosíntesis; isótopo de carbono; PEPC; CAM en Angiospermas.

\section{INTRODUCTION}

Crassulacean Acid Metabolism, CAM, is a carbon concentrating mechanism present in approximately 5 to $10 \%$ of vascular plants, comprising approximately 35 botanical families (Table 1). CAM species have been reported among pteridophytes (Keeley 1998, Holtum and Winter 1999, Rut et al. 2008), gymnosperms (Ting 1985, Vovides et al. 2002) but mainly in angiosperms, both monocotyledonous and dicotyledonous species (Ting 1989, Sayed 2001). CAM has been well reviewed from a number of different perspectives and there is considerable information available (e.g. Dodd et al. 2002, Black \& Osmond 2003, Luttge 2004, Cushman 2005, Cushman et al. 2008). The aim of this review is to highlight some of the intriguing aspects of the evolution of CAM and raise a possible mechanism behind its multiple reappearances.

The main characteristic of CAM is nocturnal uptake of carbon via the enzyme phosphoenolpyruvate carboxylase (PEPC) to form organic acid (malic acid) which accumulates in the cellular vacuole until the following morning. There is considerable variation in the expression of CAM, which may be triggered by environmental conditions, stage of development or be constitutively present in a particular species (Ting 1985, Dodd et al. 2002, Cushman et al. 2008, Motomura et al. 2008).

Current thinking is that the first appearance of CAM might date back 250-300 million years ago with the evolution of aquatic ferns (Keely \& Rundell 2003) and early gymnosperms (Vovides et al. 2002). This is in contrast to $\mathrm{C}_{4}$ metabolism, which first arose in grasses 24-35 million years ago (Sage 2004). Several studies demonstrate the evolutionary flexibility of CAM, given by different patterns of evolution across plant families, including polyphyletic origins and reversal events (Reinert et al. 2003, Crayn et al. 2004, Motomura et al. 2008, Silveira et al. 2009). Multiple independent evolution of CAM is likely to be facilitated by the fact that there are no unique enzymes or metabolic reactions specifically required for CAM, although CAM-specific PEPC-isoforms have evolved (Ermolova et al. 2003, Gerhrig et al. 2005, Vaasen et al. 2006).

Table 1. List of botanical families with at least one CAM species reported. * yet to be confirmed.

Tabela 1. Lista de famílias botânicas com, pelo menos, uma espécie CAM. * ainda por ser confirmado.

\begin{tabular}{|c|c|}
\hline Pteridophytes & $\begin{array}{l}\text { Isoetaceae } \\
\text { Polypodiaceae } \\
\text { Vittariaceae }\end{array}$ \\
\hline Gimnosperm & $\begin{array}{l}\text { Cycadaceae } \\
\text { Welwitschiaceae }\end{array}$ \\
\hline $\begin{array}{l}\text { Angiosperm } \\
\text { Dicotyledons }\end{array}$ & $\begin{array}{l}\text { Aizoaceae } \\
\text { Crassulaceae } \\
\text { Asclepiadaceae } \\
\text { Asteraceae } \\
\text { Cactaceae } \\
\text { Clusiaceae } \\
\text { Crassulaceae } \\
\text { Cucurbitaceae } \\
\text { Didieraceae } \\
\text { Euphorbiaceae } \\
\text { Geraniaceae } \\
\text { Gesneriaceae } \\
\text { Lamiaceae } \\
\text { Oxalidaceae } \\
\text { Plantaginaceae } \\
\text { Piperaceae } \\
\text { Portulacaceae } \\
\text { Rubiaceae } \\
\text { Salvadoraceae } \\
\text { Vitaceae }\end{array}$ \\
\hline $\begin{array}{l}\text { Angiosperm } \\
\text { Monocotyledons }\end{array}$ & $\begin{array}{l}\text { Agavaceae } \\
\text { Aloaceae } \\
\text { Amarylllidaceae } \\
\text { Araceae } \\
\text { Bromeliaceae } \\
\text { Commelinaceae } \\
\text { Dracaenaceae } \\
\text { Liliaceae } \\
\text { Orchidaceae } \\
\text { Rapataceae* }\end{array}$ \\
\hline
\end{tabular}


CAM confers higher water use efficiency and is intrinsically associated with water-limited environments (Cushman 2001), including epiphytic habitats, under both sun and shade conditions (Lüttge 2002). Water availability for epiphytic plants is irregular and plants tend to endure drought stress between precipitation events. It is estimated that CAM plants fix 10 to $40 \mathrm{~g}$ of carbon for every $1,000 \mathrm{~g}$ of water transpired. $\mathrm{C}_{3}$ and $\mathrm{C}_{4}$ plants fix $1-3 \mathrm{~g}$ and $2-5 \mathrm{~g}$, respectively for the same amount of transpiration (Nobel 2009). Additionally, in the aquatic environment, CAM offers the advantage of a concentrating mechanism optimizing carbon uptake during the night period, because in several natural water habitats photosynthetic rate can be limited by reduced $\mathrm{CO}_{2}$ availability (Robe \& Griffiths 2000, Rut et al. 2008).

\section{CAM DIEL CYCLE}

In what has been described as a typical CAM plant (Figure 1), nighttime accumulation of organic acids is designated phase $\mathrm{I}$, whereas daytime $\mathrm{CO}_{2}$ recovery (via decarboxylation of accumulated organic acids) and assimilation (via the Calvin-Benson cycle) comprises phase III. These two phases are separated by transitional periods: phase II is the early morning burst of net $\mathrm{CO}_{2}$ uptake, and phase IV is characterized by afternoon stomatal opening (Osmond 1978). During phases II and IV both Rubisco and PEPC are active in carbon uptake (Griffiths et al. 1990, Reinert \& Griffiths 1999).

PEPC catalyzes the irreversible $\beta$-carboxylation of phosphoenolpyruvate (PEP) using bicarbonate, yielding oxaloacetate (OAA) and inorganic phosphate (Chollet et al. 1996). OAA is then reduced by NADPH yielding malate. The 3-carbon substrate, PEP, is produced by glycolysis of storage starch or soluble sugars formed in the previous day. The final $4 \mathrm{C}$ product, malic acid, moves through the tonoplast via specific channels, following active transport of protons via the $\mathrm{H}^{+}$-ATPase pump (Lüttge 1987, Lüttge et al. 2000) and malate is stored in the vacuole. The end of the night period marks the end of phase I.

Daytime carboxylation via the Calvin-Benson cycle, phase III, is preceded by decarboxylation of stored malate, which can be mediated by one or a combination of three enzymes: NAD-dependent malic enzymes (NAD-ME), NADP-dependent malic enzymes (NADP-ME) and phosphoenolpyruvate carboxykinase (PEPcK), depending on the species, yielding pyruvate and/or PEP and $\mathrm{CO}_{2}$ (Christopher $\&$ Holtum 1996). The rate-limiting step during phase III may be malate efflux from the vacuole, malate decarboxylation in the cytoplasm, or assimilation of $\mathrm{CO}_{2}$ via Rubisco in the chloroplasts. Daytime carbon assimilation via Rubisco is strictly light dependent while stomata are closed leading to high internal partial pressure of $\mathrm{CO}_{2}$. The balance between the two carboxylation enzymes during the CAM diel cycle in living tissue can be studied using gas exchange techniques associated with carbon isotope analyses, the so called "on-line" carbon discrimination (Griffiths et al. 1990).

\section{CARBON ISOTOPES}

The use of carbon isotope signatures in plants is central to the study of CAM (and $\mathrm{C}_{4}$ ) because the distribution of the three photosynthetic modes can be assessed using the ratio of stable carbon isotopes (Smith 1972, Ting 1985). The chemical properties of the carbon isotopes ${ }^{12} \mathrm{C}$ and ${ }^{13} \mathrm{C}$, differ slightly, which in turn determines their relative proportion in organic and inorganic matter (Smith 1972). Carbon isotope fractionation can be thought of as the variation in the stable isotopes molar ratio $\left({ }^{13} \mathrm{C} /{ }^{12} \mathrm{C}\right)$ expressed during the formation/destruction of chemical bonds involving carbon atoms, and is expressed with the ${ }^{\delta 13} \mathrm{C}$ notation as "units per mille" (\%).

The observed difference in the carbon isotope signature of plant material is due to fractionation of ${ }^{12} \mathrm{C}$ and ${ }^{13} \mathrm{C}$ in photosynthetic carbon fixation (O'Leary 1988). One of the main fractionation points in vascular plants is during diffusion through the stomata, which favours ${ }^{12} \mathrm{C}$. The other major fractionation point is the carboxylation step, which can be mediated by Rubisco or PEPC. Rubisco discriminates against ${ }^{13} \mathrm{C}$ and PEPC, which does not utilize $\mathrm{CO}_{2}$, but rather, the hydrated form of inorganic carbon, bicarbonate $\left(\mathrm{HCO}_{3}^{-}\right.$), favors ${ }^{13} \mathrm{C}$. The isotopic signature of $\mathrm{C}_{3}$, $\mathrm{C}_{4}$ and CAM plants is thus a result of the primary carboxylating enzyme that dominates $\mathrm{CO}_{2}$ uptake. $\mathrm{C}_{4}$ plants are less depleted in ${ }^{13} \mathrm{C}$ than $\mathrm{C}_{3}$ plants, and in CAM plants, because atmospheric $\mathrm{CO}_{2}$ is fixed by both PEPC (mainly at night) and Rubisco (daytime), the isotope signature falls somewhere in between that of $\mathrm{C}_{3}$ and $\mathrm{C}_{4}$ plants, depending on the contribution of 
phase I to overall carbon fixation. Although reported limits vary because some plants utilize intermediate photosynthetic modes, the isotopic signature of plants generally falls between -7 and $-35 \%$, with $\mathrm{C}_{4}$ plants having values between -7 and $-15 \%$, CAM often between -10 and $-22 \%$, although it can go to $-29 \%$, and $\mathrm{C}_{3}$ between -20 and $-35 \%$ (Allaway et al. 1974). Medina et al. (1977) and O'Leary (1988) proposed and Winter and Holtum (2002) confirmed for a number of species that the relationship between the carbon isotope ratio and the proportion of dark and light $\mathrm{CO}_{2}$ fixation in CAM plants is linear.

In "on-line" discrimination, activation and deactivation of the two carboxylation enzymes present in CAM cycle, Rubisco and PEPC can be inferred. As the enzymes discrimination values differ (27\%o, for assimilation via $\mathrm{C}_{3}$ pathway and 5.7\%o for the $\mathrm{C}_{4}$ ) the determination of the carbon isotope ratio of the air passing a leaf reveals the isotope discrimination happening during photosynthesis (Fig 1) (Griffiths et al. 1990, Reinert \& Griffiths 1999).

\section{ANCIENT CAM}

As presently understood, CAM is limited to vascular plants, and the initial appearance of this photosynthetic metabolism is associated with pteridophytes. CAM has been described in epiphytic and aquatic pteridophytes, such as Dictymia (Drynariaceae), Isoetes (Isoetaceae), Plantycerium (Polypodiaceae), Pyrrosia (Polypodiaceae) and Vittaria (Vittariaceae) (Keeley 1998, Robe \& Griffiths 2000, Martin et al. 2005, Rut et al. 2008). Estimates of the evolution of Isoetes date from 230-250 million years ago, the Triassic period (DiMichele \& Bateman 1996, Rascio 2002), a period of relatively low atmospheric partial pressure of $\mathrm{CO}_{2}$ (Berner 1994, Laws et al. 2002). CAM submerged macrophytes are all secondarily aquatic plants (plants that have returned to aquatic life after having spent some of their evolutionary history on land as terrestrial plants(Rascio 2002). However, due to non-specific anatomical characteristics of CAM plants and the difficulties in discerning CAM through ${ }^{\delta 13} \mathrm{C}$, the timing of appearance of CAM among secondary aquatic macrophytes is still not determined (Rascio 2002).

Among other ancient CAM plants, a weak form of CAM, CAM-cycling, was reported in the cycad Dioon edule Lindl. (Vovides et al. 2002) This genus was considered the basal-most clade in the suborder Zamiineae (Chaw et al. 2005). Cycads (Cycadaceae) also appear to have a Paleozoic origin (Crane 1988, Vovides et al. 2002) and the presence of CAM might have conferred an additional advantage during the drying climates which marked the end of the Paleozoic Era (Vovides et al. 2002). CAM is also found among another gymnosperm, Welwitschia (von Willert 2005), one of the three genera of Gnetales. This group was originally seen as the sister-group of angiosperms, because of their morphological similarities such as flower-like reproductive structures and double fecundation. However, more recent analysis based on different gene data sets showed conifers as the closest relatives of Gnetales (Chaw et al. 1998, Braukmann et al. 2009).

\section{PEPC}

PEPC is a cytoplasmic enzyme involved in both anapleurotic and photosynthetic metabolism. PEPC catalyzes the irreversible carboxylation of PEP using $\mathrm{HCO}_{3}^{-}$in the presence of $\mathrm{Mg}_{2}^{+}$(or $\mathrm{Mn}_{2}^{+}$) and yields oxaloacetate and Pi. Among the functions of PEPC is regulation of cellular osmolarity and $\mathrm{pH}$, and replenishment of Krebs cycle intermediates, thus providing carbon skeletons for nitrogen assimilation and amino acid biosynthesis (Nimmo 2006, Xu et al. 2006). Provision of Krebs cycle intermediates is especially important for plants during intensive growth and/or activity of certain tissues. For example, expression of PEPC in legume root nodules is particularly enhanced in order to provide enough energy and carbon skeletons for nitrogen fixation (Vance 2008). Stylet chloroplasts of Nicotiana tabacum L. are devoid of Rubisco and the light-driven photosynthetic flux is functionally coupled to PEPC mediated formation of malate. This reaction enables re-utilization of respiratory $\mathrm{CO}_{2}$ during pollen tube elongation (Jansen et al. 1992). In stomatal opening, the malate anion functions as a solute, decreasing water potential of the guard cells favoring water movement into these cells (Tarczynski 1993).

\section{PEPC REGULATION}

PEPC is widely distributed from bacterial and archaeal to vascular plant species (including 
nonphotosynthetic bacteria and protozoa), but is absent from fungi and animals (Lepiniec et al. 1994, Izui et al. 2004). Several PEPC isoforms have been detected immunologically, and it is well recognized that PEPC arises from a multigene family (Lepiniec et al. 1994, Nimmo 2006, Xu et al. 2006). Plant PEPC is an allosteric enzyme often found as a tetramer of identical $\sim 95-110-\mathrm{kDa}$ subunits, although exceptions exist in the Archaea and green microalgae ( $\mathrm{Xu}$ et al. 2006). The work of $\mathrm{Xu}$ et al. (2006) with Sorghum showed that the strictly conserved, C-terminal glycine residue in PEPC is crucial for overall catalysis because even a modest, neutral alteration of the PEPC C-terminal hydrogen atom side chain is detrimental to enzyme function.

Vascular plant PEPC is activated by reversible phosphorylation of a specific serine residue near the amino terminus, mediated by a dedicated Ser/Thr kinase, PEPC-Kinase, and an opposing heterotrimeric protein phosphatase 2A. Post-translational regulation results in both improved catalytic activity and increased tolerance to malate. PEPC-Kinase is the smallest protein kinase $(\sim 31-\mathrm{kDa})$, believed to be under control of a circadian clock and synthesized de novo every night. Originally, PEPC-kinase was considered to be a major controlling point of CAM (Nimmo 2000), however more recent work (Taybi et al. 2004) comparing PEPC and PEPC-Kinase mRNA expression with day/night patters of gas exchange, organic acid and soluble sugars in Clusia species revealed that the diel regulation of PEPC-Kinase is a consequence of the circadian rhythm of CAM metabolite cycling rather than a major controlling factor for the temporal separation of carboxylation phases of CAM. Sullivan et al. (2004) working with Glycine max L. reported the expression patterns of PEPC and PEPC-Kinase gene family (GmPpc and $\mathrm{GmPpcK}$ ), including one encoding a bacterial-type Ppc. The PEPC expression patterns do not match those of any of the PEPC-K, arguing against the existence of specific PEPC and PPCK gene expression partners. Additionally, Xu et al. (2007), also working with G. max, proposed that the expression of GmPpcK2 and GmPpcK3 homologs and GmPpc7 are the key molecular steps in the regulatory phosphorylation system within mature nodules.

Most plant PEPC genes (from C3, CAM or $\mathrm{C}_{4}$ ) are formed by 10 exons and show a highly conserved structure (Chollet et al. 1996). $\mathrm{C}_{4}$-PEPC is only expressed in the mesophyll cell, whereas non-photosynthetic PEPC may be expressed in different tissues or organs, providing evidence for new expression patterns for the expression of $\mathrm{C}_{4}$ photosynthesis (Svensson et al. 2003). CAM-PEPC, on the other hand, is temporally regulated to function mostly at night. $\mathrm{C}_{4}$-PEPC and, especially, CAMPEPC function in a different metabolic context with substantially higher substrate and product concentrations, which probably called for altered kinetics and/or regulation of the enzyme. $\mathrm{C}_{4}$-PEPC shows a rapid (few seconds) turnover in the order of magnitude of $1-10 \mathrm{mM}$ of ${ }^{4} \mathrm{C}$ acids, and CAMPEPC turns over $100-500 \mathrm{mM}$ pools of ${ }^{4} \mathrm{C}$ acids in $24 \mathrm{~h}$ cycles. A comprehensive study of a PEPC gene family was carried out for Kalanchoe pinnata (Lam.) Pers. (Crassulaceae) (Gehrig et al. 2005). The authors found and sequenced fragments from seven isoenzymes, of which only one was suggested to be responsible for the photosynthetic functions of CAM.

The wide distribution of PEPC and the many different roles of this enzyme suggest that PEPC genes can provide powerful markers not only for the molecular evolution of the enzyme itself but for the metabolic pathways where the enzyme is involved and the organisms that show such pathways.

\section{CAM EVOLUTION}

Unraveling the evolution of both CAM and $\mathrm{C}_{4}$ pathways is contributing to the elucidation of the molecular evolution of PEPC (Hermans \& Westhoff 1990, Lepeniec et al. 1993, 1994, Slocombe et al. 1993, Toh et al. 1994, Nakagawa et al. 2003, Sanchez \& Cejudo 2003). Nevertheless, it is important to note that although PEPC is a key enzyme for both photosynthetic pathways, and certainly crucial to the development of CAM and $\mathrm{C}_{4}$, PEPC evolution does not necessarily reflect that of the photosynthetic pathway. In the last decade it has been proposed that one of the primary events in the evolution of CAM and C4 plants may have been the development of a regulatory mechanism that generates novel patterns of gene expression of PEPC and of other enzymes involved in temporal and spatial expression patterns of $\mathrm{CAM}$ and $\mathrm{C}_{4}$ (Hermans \& Westhoff 
1990, Lepeniec et al. 1993, Svensson et al. 2003). Lepeniec et al. (1994) suggested that, following gene duplication and divergence, an isoform with a specific mode of regulation, at least at the level of gene expression, could have been conserved in the plant families containing $\mathrm{C}_{4}$ species. Further, more recent modifications in the kinetic or regulatory properties of the $\mathrm{C}_{4}$-PEPC would have taken place differently in the various species after the enzyme had acquired its function in $\mathrm{C}_{4}$ photosynthesis.

At this point we would like to re-address a basic point regarding the debate on the evolution of CAM: the question as to whether the multiple aspects involved in this metabolism are parts of a whole, with an identity of its own, or if these aspects represent independent phylogenetic units with independent evolutionary histories, functioning together and producing a trait (CAM). However, to properly address this question beyond rhetoric, it would be necessary to provide empirical evidence of the mechanism of convergent evolution that made it possible for CAM to have such broad distribution among plant species. The lack of a framework for the investigation of the evolution of CAM, other than the evolution of its best studied enzyme, PEPC, has puzzled at least another author. Monson (2003) pointed out our limitation to explain why or how $\mathrm{C}_{4}$ (and we would include CAM in a similar scenario) photosynthesis evolved so many times independently and why there are certain patterns in its taxonomic distribution. Monson (2003) noted that $\mathrm{C}_{4}$ is absent in canopy-forming forest tree species and the paucity

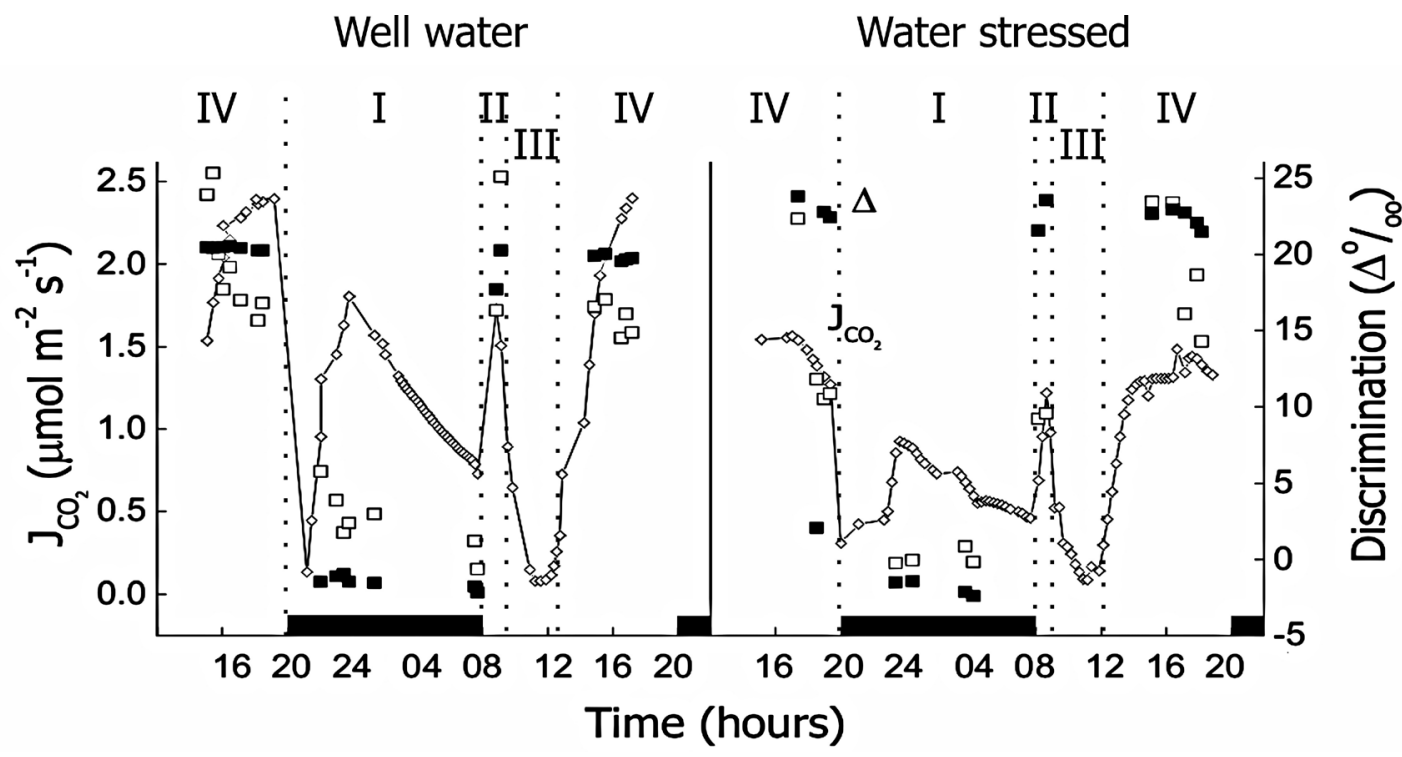

Figure 1. Gas exchange (.), showing the four phases of CAM (roman numbers) and on-line carbon isotope discrimination in Neoregelia cruenta (R. Graham) L.B. Smith (Bromeliaceae) with regular water supply (left) and under water stress (right). Close squares represent calculated values according to the model proposed by Farquhar et al. (1989), where $\Delta=a+(b-a) \mathrm{p}_{\mathrm{i}} / \mathrm{p}_{\mathrm{a}} ; a$ refers to the theoretical carbon isotopic fractionation due to the diffusion in air $(4.4 \%), b$ to the fractionation occurring during carboxylation $\left(27 \%\right.$, for assimilation via $\mathrm{C}_{3}$ pathway and $5.7 \%$ for the $\left.\mathrm{C}_{4}\right)$ and $\mathrm{p}_{\mathrm{i}} / \mathrm{p}_{\mathrm{a}}$ refers to the partial pressure of $\mathrm{CO}_{2}$ inside and outside the stomata chamber. Open squares represent measured values of the carbon isotope ratio of the reference and analysis air stream following gas exchange measurements. Black bars represent the dark period. Gas exchange was measured using a Walz mini-cuvette system (CMS 400) with an external IRGA (Binos 100 Walz, Effeltrich, Germany). Leaf cuvette day/night temperature of $22^{\circ} \mathrm{C}$ and incident PFD of $300 \mu \mathrm{mol}$ photon $\mathrm{m}^{2} \mathrm{~s}^{-1}$. During phase II, isotope ratio signal shifts from $\mathrm{C}_{4}$ to $\mathrm{C}_{3}$ carboxylation as $\Delta$ values increase and during phase IV from $\mathrm{C}_{3}$ to $\mathrm{C}_{4}$ carboxylation as $\Delta$ values decrease, showing that both enzymes (Rubisco and PEPC) are active. During phase I (night period), $\Delta$ approach theoretical values of carbon assimilation via PEPC. During phase III no $\Delta$ values are presented as stomata are closed (Reinert 1995).

Figura 1. Trocas gasosas (), mostrando as quatro fases de CAM (algarismos romanos) e descriminação isotópica on-line em Neoregelia cruenta (R. Graham) L.B. Smith (Bromeliaceae) com água (esquerda) e sem água (direita). Quadrados fechados representam valores calculados a partir do modelo proposto por Farquhar et al. (1989), onde $\Delta=a+(b-a) p_{i} / p_{a}$; a refere-se ao fracionamento teórico do isótopo de carbono em função da difusão no ar (4.4\%o), b refere-se ao fracionamento teórico do isótopo em função da carboxilação (27\%o, para assimilação via rota $C_{3}$ e $5.7 \%$ via rota $\left.C_{4}\right)$ e $p_{i} / p_{a}$ refere-se à pressão parcial de $\mathrm{CO}_{2}$ dentro e fora da câmara sub-estomática. Quadrados abertos representam valores de razão isotópica do gás referência e análise após medidas de trocas gasosas. A barra em preto representa o periodo de escuro. Trocas gasosas foram medidas pelo Walz mini-cuvette system (CMS 400) com IRGA externo (Binos 100 Walz, Effeltrich, Germany). A temperatura da câmara foliar foi de $22^{\circ} \mathrm{C}$ e luz incidente de $300 \mu \mathrm{mol}$ photon $\mathrm{m}^{2} \mathrm{~s}^{-1}$. Durante a fase II, o sinal da razão isotópica ( $\Delta$ ) aumenta à medida que a carboxilação muda de $C_{4}$ para $C_{3}$; e durante a fase IV $\Delta$ diminui à medida que a carboxilação muda de $C_{3}$ para $C_{4}$, mostrando que ambas enzimas (Rubisco e PEPC) estão ativas. Durante a fase I (período noturno), $\Delta$ aproxima-se dos valores teóricos de assimilação de carbono via PEPC. Durante a fase III não há medidas de $\Delta$ porque os estômatos ficam fechados (Reinert 1995). 
of $\mathrm{C}_{4}$ species within eudicots compared to monocots. Similarly, among CAM species the genus Clusia is the only example of a CAM tree, although among CAM plants there is no clear predominance of monocots over dicot species. Monson (2003) argued that the evolution of $\mathrm{C}_{4}$ photosynthesis is largely a story of gene duplication while plants are still in the ancestral, $\mathrm{C}_{3}$ state. In his own words: "Once a reservoir of key, duplicated, and preserved $\mathrm{C}_{3}$ genes is present, a small amount of subsequent modification within gene promoter regions is all that is necessary to transform certain $\mathrm{C}_{3}$ patterns of gene expression to $\mathrm{C}_{4}$ patterns."

Corroborating the gene duplication hypothesis, the work of Amoutzias et al. (2004) with bHLH proteins and nuclear receptor proteins combining genomic data, domain architecture and proteinprotein interactions, provided the first empirical evidence that scale-free protein networks can emerge through single-gene duplications. bHLH (basic helixloop-helix) comprises an ancient class of eukaryotic transcription factors that are found in fungi, plants and animals. It is presently believed that gene duplication event(s), both large-scale and single-gene duplication, are the predominant mechanism for the generation of complex networks, such as new members of a protein family, and so is central to the evolution of complex traits. Studies on the evolution of the CAM pathway would certainly benefit from a similar approach and should be pursued. In conclusion CAM (and $\mathrm{C}_{4}$ ) evolution should be investigated as a sub-network that evolved by gene duplication from a pre-existing network such as the non photosynthetic $\mathrm{C}_{4}$ cycle.

ACKNOWLEDGEMENTS: The authors are grateful to Leandro Salles for his valueable inputs and to Washington University in St Louis for financial support that allowed Fernanda Reinert to visit and study in Robert Blankenship's laboratory.

\section{REFERENCES}

ALLAWAY, W.G.; OSMOND, C.B. \& TROUGHTON, J.H. 1974. Environmental regulation of growth photosynthetic pathway and carbon isotope discrimination ratio in plants capable of crassulacean acid metabolism. Pp. 195-202. In: R.L. Bieleski, A.R. Ferguson, M.M. Cresswell (eds.) Mechanisms of Regulation of Plant Growth. Bulletin 12. The Royal Society of New Zealand, Wellington. 934p.

AMOUTZIAS, G.D.; ROBERTSON, D.L.; OLIVER, S.G. \& BORNBERG-BAUER, E. 2004. Convergent evolution of gene networks by single-gene duplications in higher eukaryotes. EMBO Reports, 5(3): 274-279.

BORNBERG-BAUER, E. 2004. Convergent evolution of gene networks by single-gene duplications in higher eukaryotes. EMBO Reports, 5(3): 274-279.

BERNER, R.A. 1994. Geocarb II: a revised model of atmospheric $\mathrm{CO}_{2}$ over Phanerozoic time.American Journal of Science, 294: 56-91.

BLACK, C.C. \& OSMOND, C.B. 2003. Crassulacean acid metabolism photosynthesis: 'working the night shift'. Photosynthesis Research, 76: 329-341.

BRAUKMANN, T.W.A.; KUZMINA, M. \& STEFANOVIC, S. 2009. Loss of all plastid ndh genes in Gnetales and conifers: extent and evolutionary significance for the seed plant phylogeny. Current Genetics, 55: 323-337.

CHAW, S.-M.; WALTERS, T.W.; CHANG, C.-C.; HU, S.-H. \& CHEN, S.-H. 2005. A phylogeny of cycads (Cycadales) inferred from chloroplast matK gene, trnK intron, and nuclear rDNA ITS region Molecular Phylogenetics and Evolution, 37: 214-234.

CHOLLET, R.; VIDAL, J. \& O'LEARY, M. 1996. Phosphoenolpyruvate carboxylase: a ubiquitous, highly regulated enzyme in plants. Annual Review of Plant Physiology - Plant Molecular Biology, 47: 273-298.

C H R I S T O P H E R, J . T.\& H O L T U M, J . A . M . 1996. Patterns of carbon partitioning in leaves of crassulacean acid metabolism species during deacidification. Plant Physiology 112: 393-399.

CRANE, P. 1988. Major clades and relationships in higher gymnosperms. Pp. 218-272. In: C.B. Beck. (ed.) Origin and Evolution of Gymnosperms. Columbia University Press, New York. 504p.

CRAYN, D.M.; WINTER, K. \& SMITH, J.A.C. 2004. Multiple origins of crassulacean acid metabolism and the epiphytic habit in the Neotropical family Bromeliaceae. Procedures of the National Academy of Sciences USA, 101: 3703-3708.

CUSHMAN, J.C. 2001. Crassulacean acid metabolism: recent advances and future opportunities. Plant Physiology, 127: 1439-1448.

CUSHMAN, J.C. 2005. Crassulacean acid metabolism: recent advances and future opportunities. Functional Plant Biology, 32(55): 375-380.

CUSHMAN, J.C.; AGARIE, S.; ALBION, R.L.; ELLIOT, S.M.; TAYBI, T. \& BORLAND, A.M. 2008. Isolation and characterization of mutants of common ice plant deficient in crassulacean acid metabolism. Plant Physiology, 147: 228-238. 
DIMICHELE, W.A. \& BATEMAN, R.M. 1996. The rhizomorphic lycopsids: a case study in paleobotanical classification. Systematic Botany, 21: 535-552.

DODD, A.N.; BORLAND, A.M.; HASLAM, R.P.; GRIFFITHS, H. \& MAXWELL, K. 2002. Crassulacean acid metabolism: plastic, fantastic. Journal of Experimental Botany, 53(369): $569-580$

ERMOLOVA, N.V., CUSHMAN, M.A., TAYBI, T., CONDON, S.A., CUSHMAN, J.C. \& CHOLLET, R. 2003. Expression, purification, and initial characterization of a recombinant form of plant PEP-carboxylase kinase from CAM-induced Mesembryanthemum crystallinum with enhanced solubility in Escherichia coli. Protein Expression and Purification, 29: 123-131.

FARQUHAR, G.D.; EHLERINGER, J.R. \& HUBICK K.T. 1989. Carbon isotope discrimination and photosynthesis. Annual Review of Plant Physiology and Molecular Biology, 49: 503-537.

GEHRIG, H.H.; WOOD, J.A.; CUSHMAN, M.A.; VIRGO, A.; CUSHMAN, J.C. \& WINTER, K. 2005. Large gene family of phosphoenolpyruvate carboxylase in the crassulacean acid metabolism plant Kalanchoe pinnata (Crassulaceae) characterised by partial cDNA sequence analysis. Functional Plant Biology, 32: 467-472.

GRIFFITHS, H.; BROADMEADOW, M.S.J.; BORLAND, A.M. \& HETHERINGTON, C.S. 1990. Short-term changes in carbonisotope discrimination between $\mathrm{C}_{3}$ and $\mathrm{C}_{4}$ carboxylation during crassulacean acid metabolism. Planta, 181: 604-610.

HERMANS, J. \& WESTHOFF, P. 1990. Analysis of expression and evolutionary relationships of phosphoenolpyruvate carboxylase genes in Flaveria trinervia $\left(\mathrm{C}_{4}\right)$ and F. pringlei $\left(\mathrm{C}_{3}\right)$. Molecular \& General Genetics, 224: 459-468.

HOLTUM, J.A.M. \& WINTER, K. 1999. Degrees of crassulacean acid metabolism in tropical epiphytic and lithophytic ferns. Australian Journal of Plant Physiology, 26: 749-757.

IZUI, K.; MATSUMURA, H.; FURUMOTO, T. \& KAI Y. 2004. Phosphoenolpyruvate carboxylase: A New Era of Structural Biology. Annual Review of Plant Biology, 55: 69-84.

JANSEN, M.A.K.; SESSA, G.; MALKIN, S. \& FLUH, R. 1992. PEPC-mediated carbon fixation in transmitting tract cells reflects style-pollen tube interactions. The Plant Journal, 2(4): 507-515.

KEELEY JE. 1998. CAM photosynthesis in submerged aquatic plants. Botanical Review, 64: 121-175.

KEELEY, J.E. \& RUNDEL, P.W. 2003. Evolution of CAM and $\mathrm{C}_{4}$ carbon-concentrating mechanisms. International Journal of Plant Science, 164(3): S55-S77.
LAWS, E.A.; POPP, B.N. CASSAR, N. \& TANIMOTO, J. 2002. ${ }^{13} \mathrm{C}$ discrimination patterns in oceanic phytoplankton: likely influence of $\mathrm{CO}_{2}$ concentrating mechanisms, and implications for palaeoreconstructions. Functional Plant Biology, 29: 323-333.

LEPINIEC, L.; KERYER, E.; PHILIPPE, H.; GADAL, P. \& CRETIN, C. 1993. Sorghum phosphoenolpyruvate carboxylase gene family: structure, function and molecular evolution. Plant Molecular Biology, 21: 487-502.

LEPINIEC, L.; VIDAL, J.; CHOLLET, R.; GADAL, P. \& CRETIN, C. 1994. Phosphoenolpyruvate carboxylase: structure, regulation and evolution. Plant Sciences, 99: 111-124.

LÜTTGE, U. 1987. Carbon dioxide and water demand: Crassulacean acid metabolism (CAM), a versatile ecological adaptation exemplifying the need for integration in ecophysiological work. New Phytologist, 106: 593-629.

LÜTTGE, U. 2002. CO2-concentrating: consequences in crassulacean acid Metabolism. Journal of Experimental Botany, 53(378): 2131-2142.

LÜTTGE, U. 2004. Ecophysiology of Crassulacean Acid Metabolism (CAM). Annals of Botany, 93: 629-652.

LÜTTGE，U.; PFEIFER，T.; FISCHER-SCHLIEBS， E. \& RATAJCZAK, R. 2000. The Role of Vacuolar Malate-Transport Capacity in Crassulacean Acid Metabolism and Nitrate Nutrition. Higher Malate-Transport Capacity in Ice Plant after Crassulacean Acid Metabolism-Induction and in Tobacco under Nitrate Nutrition. Plant Physiology, 124: 1335-1347.

MARTIN, S.L.; DAVIS, R.; PROTTI, P.; LIN, T.; LIN, S.; \& MARTIN, CE 2005. The occurrence of crassulacean acid metabolism in epiphytic ferns, with an emphasis on the Vittariaceae. International Journal of Plant Science, 166(4): 623630.

MEDINA, E.; DELGADO, M.; TROUGHTON, J.H. \& MEDINA, J.D. 1977. Physiological ecology of carbon dioxide fixation in Bromeliaceae. Flora (Jena), 166: 137-52.

MONSON, R.K. 2003. Gene duplication, neofunctionalization, and the evolution of $\mathrm{C}_{4}$ photosynthesis International Journal of Plant Science, 164(3): S43-S54.

MOTOMURA, H.; YUKAWA, T.; UENO, O. \& KAGAWA, A. 2008. The occurrence of Crassulacean acid metabolism in Cymbidium (Orchidaceae) and its ecological and evolutionary implications. Journal of Plant Research, 121: 163-177.

NAKAGAWA, T.; TAKANE, K.; SUGIMOTO, T.; IZUI, K.; KOUCHI, H. \& HATA, S. 2003. Regulatory regions and nuclear factors involved in nodule-enhanced expression of a soybean 
phosphoenolpyruvate carboxylase gene: implications for molecular evolution. Molecular Genetics and Genomics, 269: 163-172.

NIMMO H.G. 2000. The regulation of phosphoenolpyruvate carboxylase in CAM plants. Trends in Plant Science, 5: 75-80.

NIMMO H.G. 2006. Control of phosphoenolpyruvate carboxylase in plants. In: W.C. Plaxton, M.T. McManus (eds). Control of primary metabolism in plants. Annual Plant Reviews 22. Blackwell Publishing Ltd. UK.

NOBEL, P.S. 2009. Physicochemical and Environmental Plant Physiology, Fourth Edition. Elsevier Inc., Canada. 475p.

O'LEARY, M.H. 1988. Carbon isotopes in photosynthesis. BioScience, 38: 328-335.

OSMOND, C.B. 1978. Crassulacean acid metabolism: a curiosity in context. Annual Review of Plant Physiology, 29: 379-414.

RASCIO, N. 2002. The Underwater Life of Secondarily Aquatic Plants: Some Problems and Solutions. Critical Reviews in Plant Sciences, 21(4): 401-427.

REINERT, F. 1995. On the Bromeliaceae of the restinga of Barra de Maricá in Brazil: environmental influences on the expression of CAM. PhD thesis, University of Newcastle, UK. 234p.

REINERT, F. \& GRIFFITHS, H. 1999. Activity of RUBISCO and PEPC during the dial cycle of CAM. Leandra, 14: 65-70.

REINERT, F.; RUSSO, C.A.M. \& SALLES, L.O. 2003. The evolution of CAM in the subfamily Pitcairnioideae (Bromeliaceae). Biology Journal of the Linnaean Society, 80: 261-268.

ROBE, W.E. \& GRIFFITHS, H. 2000. Physiological and photosynthetic plasticity in the amphibious, freshwater plant, Littorella uniflora, during the transition from aquatic to dry terrestrial environments. Plant Cell and Environment, 23: 1041-1054.

RUT, G.; KRUPA, J.; MISZALSKI, Z; RZEPKA, A. \& ŚLESAK, I. 2008. Crassulacean acid metabolism in the epiphytic fern Platycerium bifurcatum. Photosynthetica, 46(1): 156-160.

SAGE, R.F. 2004. The evolution of $\mathrm{C}_{4}$ photosynthesis. New Phytolologist, 161: 341-370.

SANCHEZ, R. \& CEJUDO, F.J. 2003. Identification and Expression Analysis of a Gene Encoding a Bacterial-Type Phosphoenolpyruvate carboxylase from Arabidopsis and rice. Plant Physiology, 132: 949-957.

SAYED, O.H. 2001. Crassulacean acid metabolism 1975-2000 a check list. Photosynthetica, 39(3): 339-352.
SILVERA, K.; SANTIAGO, L.S.; CUSHMAN, J.C. \& WINTER, K. 2009. Crassulacean Acid Metabolism and Epiphytism Linked to Adaptive Radiations in the Orchidaceae. Plant Physiology, 149: $1838-1847$.

SLOCOMBE, S.P.; WHITELAM, G.C. \& COCKBURN, W. 1993. Investigation of phosphoenolpyruvate carboxylase (PEPCase) in Mesembryanthemum crystalinum L. in $\mathrm{C}_{3}$ and CAM photosynthetic states. Plant Cell and Environment, 16: 403-411.

SMITH, B.N. 1972. Natural abundance of the stable isotopes of carbon in biological systems. Bioscience, 22: 226-231.

SMITH, B.N. \& EPSTEIN, S. 1971. Two categories of ${ }^{13} \mathrm{C} /{ }^{12} \mathrm{C}$ ratios for higer plants. Plant physiology, 47: 380-384.

SULLIVAN, S.; JENKINS, G.I. \& NIMMO, H.G. 2004. Roots, cycles and leaves. Expression of the phosphoenolpyruvate carboxylase kinase gene family in soybean Plant Physiology, 135(4): 2078-2087.

SVENSSON, P.; BLÄSING, O.E. \& WESTHOFF, P. 2003. Evolution of $\mathrm{C}_{4}$ phosphoenolpyruvate carboxylase. Archives of Biochemistry and Biophysics, 414: 180-188.

TARCZYNSKI, M.C. \& OUTLAW-Jr., W.H. 1993. The interactive effects of $\mathrm{pH}, \mathrm{L}$-malate, and glucose-6-phosphate on guard-cell phosphoenolpyruvate carboxylase. Plant Physiology, 103(4): 1189-1194.

TAYBI, T.; NIMMO, H.G. \& BORLAND, A.M. 2004. Expression of phosphoenolpyruvate carboxylase and phosphoenolpyruvate carboxylase kinase genes. Implications for genotypic capacity and phenotypic plasticity in the expression of crassulacean acid metabolism. Plant Physiology, 135: 587-98.

TING, I.P. 1985. Crassulacean acid metabolism. Annual Review of Plant Physiology and Plant Molecular Biology, 36: 595-622.

TING, I.P. 1989. Photosynthesis of arid and subtropical succulent plants. Aliso, 12(2): 387-406.

TOH, H.; KAWAMURA, T. \& IZUI, K. 1994. Molecular evolution of phosphoenolpyruvate carboxylase Plant Cell and Environment, 17:31-43.

VAASEN, A.; BEGEROW, D. \& HAMPP, R. 2006. Phosphoenol pyruvate carboxylase genes in $\mathrm{C}_{3}$, crassulacean acid metabolism (CAM) and $\mathrm{C}_{3} / \mathrm{CAM}$ intermediate species of the genus Clusia: rapid reversible $\mathrm{C}_{3} / \mathrm{CAM}$ switches are based on the $\mathrm{C}_{3}$ housekeeping gene. Plant, Cell and Environment, 12: 2113-2123.

VANCE, C.P. 2008. Carbon and nitrogen metabolism in legume nodules. Pp 293-320. In: M.J. Dilworth, E.K. James, J.I. Sprent $\&$ W.E. Newton (eds). Nitrogen-fixing Leguminous Symbioses. Springer, Netherlands. 404p 
VOVIDES, A.P.; ETHERINGTON, J.R.; DRESSER, P.Q.; GROENHOF, A.; IGLESIAS, C. \& RAMIREZ, J.F. 2002. CAMcycling in the cycad Dioon edule Lindl. in its natural tropical deciduous forest habitat in central Veracruz, Mexico. Botanical Journal of the Linnean Society, 138: 155-162.

VON WILLERT, D.J.; ARMBRUSTER, N.; DREES, T. \& ZABOROWSKI, M. 2005. Welwitschia mirabilis: CAM or not CAM. What is the answer? Functional Plant Biology, 32: 389-395.

WINTER, K. \& HOLTUM, J.A.M. 2002. How closely do the $\delta^{13} \mathrm{C}$ values of crassulacean acid metabolism plants reflect the proportion of $\mathrm{CO}_{2}$ fixed during day and night? Plant Physiology, 129: $1843-1851$.

XU, W.; AHMED, S.; MORIYAMA, H. \& CHOLlET. R. 2006. The importance of the strictly conserved, c-terminal glycine residue in phosphoenolpyruvate carboxylase for overall catalysis: mutagenesis and truncation of gly-961 in the sorghum $\mathrm{C}_{4}$ leaf isoform. The Journal of Biological Chemistry, 281(25): 1723817245 .

XU, W.; SATO, S.J.; ClEMENTE, T.E. \& CHOLlET, R. 2007. The PEP-carboxylase kinase gene family in Glycine max (GmPpcK1-4): an in-depth molecular analysis with nodulated, non-transgenic and transgenic plants. The Plant Journal, 49: 910-923.

Submetido em 30/09/2009.

Aceito em 11/12/2009 